Сања Петровић

(Филозофски факултет, Нови Сад)
Изворни научни рад

УДК 821.163.41.09 Stefanović Venclović G.

811.163.41'367

DOI 10.19090/ppj.2020.51.77-100

\title{
КЛАУЗАЛНЕ СТРУКТУРЕ У ФУНКЦИЈИ ДОПУНЕ У ТЕКСТУ ПРОЛОШКОГ ЖИТИЈА СВЕТОГ МАКСИМА БРАНКОВИЋА ГАВРИЛА СТЕФАНОВИЋА ВЕНЦЛОВИЋА ИЗ 1744/45. ГОДИНЕ ${ }^{1}$
}

\section{САЖЕТАК}

У овом раду анализирају се са синтаксичког и семантичког аспекта клаузалне структуре у функцији допуне у рукопису Пролошког житија Светог Максима Бранковића Гаврила Стефановила Венцловића из 1744/45. године, писаном српским народним језиком с ретким наносима из српскословенског језика. Текст се налази у зборнику Житија, слова и поуке разних светих из 1744/45. године, који се чува у Архиву САНУ под инвентарним бројем 84 (270), на странама 666a-674a. Под клаузалним структурама у функцији допуне подразумевамо средства номиналног и вербалног типа у функцији изражавања допунског реченичног садржаја глагола различитих семантичких класа. У номинална средства убрајамо инфинитивне допуне у таутосубјекатском и хетеросубјекатском односу с главним предикатом и акузативне конструкције (двоструки акузатив, акузатив с герундом), а у вербална допунске реченице. Пратећи конкурентни однос међу вербалним и номиналним средствима у оквиру исте синтаксичко-семантичке позиције, покушали смо да откријемо који тип допуне доминира у језику Гаврила Стефановића Венцловића, као и то које структуре се могу сматрати књишким конструкцијама (црквенославенизмима), а које имају вернакуларни карактер, како бисмо на основу добијених резултата одредили стил језика којим је написано Пролошко житије Светог Максима Бранковића.

\footnotetext{
${ }^{1}$ Овај рад настао је у оквиру пројекта Историја српског језика (бр. 178001), који финансира Министарство просвете, науке и технолошког развоја Републике Србије, чији сам стипендиста. Проф. др Марини Курешевић захваљујем на сугестијама.
} 
КљУЧНЕ РЕЧИ: Пролошко житије Светог Максима Бранковића, Гаврил Стефановић Венцловић, старосрпски језик, синтакса, допуне.

\section{1. Увод}

\section{1. Прилике у српској књижевности XVII и XVIII века}

У барокном раздобљу српска књижевност окреће се новим узорима и прихвата нова начела употребе писаног језика. Тако је књижевност фрањеваца у Босни XVII и XVIII века писана народним језиком, а штампана или прештампавана ћирилицом, утицала на поједине српске писце, попут Рачана, а касније и Доситеја, да се определе за народни језик (Павић 1991: 16). Значајан утицај на српску књижевност XVIII века имале су руска и украјинска, а преко украјинске и пољска књижевност. Разлоге окретању словенском северу у књижевности треба тражити у католичкој противреформацији, која је била веома агресивна током читавог XVII и XVIII века. Српска књижевност је у овом периоду била без књига, штампарија и школа, што ју је стављало у незавидан положај у борби против језуитске пропаганде. Методи одбране православне вере, у виду полемичке књижевности, били су добро разрађени у украјинској књижевности будући да се Украјина нашла у сличној ситуацији током XVII века. Имајући све то у виду, не чуди да је српска књижевност у овој борби ослонац потражила управо у украјинској књижевности (Павић 1991: 17-18). Уз то, знајући за несташицу књига у словенским земљама под турском и аустријском влашћу, Русија штампа и шаље богослужбене књиге где год за њима има потребе. У оваквим друштвено-историјским околностима ствара јеромонах Гаврил Стефановић Венцловић, вредни писар и надахнути беседник из прве половине XVIII века, о чијем се животу, омеђеном сеобама Срба, не зна много, а иза кога је остало око 20000 рукописних страница писаних народним и српскословенским језиком.

\section{2. О раду Гаврила Стефановића Венцловића}

У своме раду Венцловић се користио и народним и српскословенским језиком. Када се обраћао клеру, то је чинио на српскословенском, а када се обраћао пастви, то је чинио на народном језику (Павић 1966: 23). Српскословенским језиком је писао, тј. преписивао литургијске текстове, каноне, молитве, тропаре, кондаке, акатисте и текстове за практичне потребе, 
а народиним текстове намењене образовању шире публике, који су им служили као својеврсна поучна лектира. Текстови на народном језику представљају оригиналнији део његове заоставштине. Настали су у периоду између 1732. и 1746. године. ${ }^{2}$ Мотив за употребу народног језика Венцловић је налазио у тежњи да допре до сваког слушаоца, без обзира на његову ученост и предзнање, а инспирацију је тражио и у библијским узорима. ${ }^{3}$ Венцловић је први који је почео да уводи народни језик у црквено беседништво, да у њега уноси елементе народне мудрости, усмене књижевности и поезије, као и народне називе црквених празника (Павић 1966: 45).

Венцловићева борба да књигу и њен садржај приближи широј публици, како слушалачкој тако и читалачкој, огледала се и у његовој реформи правописа и употреби поједностављене ћирилице у списима написаним народним језиком (Павић 1991: 33). Венцловић је од шест знакова, колико ће касније Вук унети у своју нову азбуку, употребљавао три $-\mu, \hbar$ и $\hbar$, с малим разликама у односу на Вука у обележавању слова $\hbar$ и $\hbar$, за шта су му признања до данас изостала (Павић 1966: 46).

Рукописи Гаврила Стефановића Венцловића, мада углавном представљају доста слободне преводе и прераде с рускословенског и других језика, посрбљене и прилагођене приликама у којима се налазило друштво његовог времена, имају немерљив значај за историју српског језика и народа. Венцловићев језик и стил носе јак печат и слику времена и средине у којој су настали, који су обележени етничким мешањима и интензивним

${ }^{2}$ Сви Венцловићеви рукописи на народном језику чувају у се Архиву САНУ, а инвентарне бројеве под којима се чувају дајемо у наставку у загадама уз попис поменутих рукописа, према подацима из: Стојановић, Љубомир. Каталог рукописа $и$ cтарих штампаних књига. Збирка Српске краљевске академије. Београд 1901. Најстарији познати Венцловићев рукопис на народном језику јесте Поученија $u$ слова разлика, настао 1732. године [94 (271)]. Око 1736. године преводи Мач духовни (у три књиге, но трећа је изгубљена) [92 (267) и 93 (268)], 1741. године Великопостник [97 (136)], 1743. године Пентикости триода [98 (272)], 1744/45. године Житија, слова и поуке [84 (270)], 1745. године Слова изабрана [101 (137)], а у две књиге 1745. и 1746. године преписује Поученије изабраноје от светаго јевгелија [99 (139) и $100(269)]$.

3 У књизи Поученија и слова разлика, писаној на народном језику, Венцловић бележи цитат Светог Павла: „Писмо које се својом памећу не разбира, оно бије и мори људе.“ (Павић 1966: 44). 
међујезичким контактима, што је Венцловићев језик и учинило „шареним”, пуним турцизама, као и екавских и ијекавских облика (Павић 1972: 177). Његово дело било је намењено читаоцима различитих друштвених слојева, различитих нивоа знања, неједнаких схватања и потреба, те можемо рећи да је у њему утиснута и слика његове публике, која се огледа кроз језик којим је писао, правопис који је користио, као и кроз тематику, стил и естетику његових дела (Павић 1991: 203). Иако Венцловић језик којим пише своје беседе назива „простим српским језиком”, а све то чини „на службу сељану некњижевном",, његов језик није потпуно чист народни језик, већ има у себи елемената црквенословенског, што не чуди будући да је као црквени човек свакодневно био у контакту с овим језиком (Јовановић 1911: 113). Венцловићево дело остаје као сведочанство о правцу у коме би се српски језик могао развијати да је одржан континуитет са старом писаном традицијом (Новаковић 1904: 180), али и о могућем развитку једне културне револуције, која би уследила да је Венцловићево дело било штампано (Павић 1972: 127) .

\section{2. Корпус истраживања}

Пролошко житије Светога Максима Бранковића је настало у периоду између 1523. и 1526. године, у периоду цветања култа о сремским Бранковићима, ${ }^{5}$ а његов писац нам је до данас остао непознат, мада се претпоставља да иза овог дела стоји неки од монаха из манастира Крушедола (Томин 2007: 142-143). Један од преписа ${ }^{6}$ овог култног списа представља и

\footnotetext{
${ }^{4}$ Цитат из поговора рукописног зборника Поученија и слова разлика из 1732. године, који се у Архиву САНУ чува под редним бројем 271.

5 Популарност култа сремских Бранковића је током турске владавине Сремом превазилазила чак и популарност култа свете лозе Немањића и имала је „национални и општебалкански карактер": око овог култа окупљали су се сви Срби, али и православни Словени (Богдановић 1991: 243). Иако му је тежиште било у Срему, развијао се и међу Србима у Угарској, али и на другим територијама током XVII и XVIII века. Како Светлана Томин (2007: 7) запажа, овај култ имао је „свесрпски” карактер, као и верску, националну и идеолошку функцију.

6 Постоји више издања Пролошког житија, а велики број преписа, као и разлике међу њима, сведоче о „великој флуктуацији текста”. Ово Пролошко житије налазило се у саставу (изгубљеног) раковачког Србљака, римничког Србљака из 1761. године, венецијанског Србљака из 1765. године и београдског Србљака из
} 
Венцловићев рукопис који се налази се у рукописној књизи Житија, слова и поуке разних светих из 1744/45. године на странама 666а-674а (ГроздановићПајић 1992: 177-179) и која се чува у Архиву САНУ под бројем 84 (270).

Као предложак за писање овог Пролошког житија Венцловић је вероватно користио рукопис Кипријана Рачанина писан 1692. и 1694. године ${ }^{7}$ будући да је и сам био његов ученик, што је често с поносом истицао. Да је овај рукопис послужио Венцловићу као узор закључујемо пре свега према садржају Венцловићевог текста, реду излагања, као и неким формулацијама, мада је Венцловићево дело „много опширније и обележено специфичном пишчевом традицијом”, „с развијенијим епизодама и дигресијама, док му је причање сликовитије и живље” (Томин 2007: 147-148). Једина Венцловићева интервенција на садржају текста, која није резултат његове стилизације текста, јесте додавање епизоде о Змај Огњеном Вуку, који протерује Максима из Срема и отима му деспотство. ${ }^{8}$

\section{3. Предмет, методологија и циљ истраживања}

Језик овог писца до сада је био истраживан на фонолошком и морфолошком нивоу, док лексика и синтакса нису систематски испитиване. Како бисмо барем донекле осветлили карактеристике језика овог писца на синтаксичком нивоу, за предмет нашег истраживања одабрали смо да истражујемо клаузалне структуре у функцији допуне у Венцловићевом

1861. године. Уз то, Пролошко житије објавио је и Алекса Вукомановић 1859. године у Гласнику друштва српске словесности на основу рукописа из XVII века, док је Венцловићев рукопис овог Житија, који се налази у зборнику с половине XVIII века, публиковао Гаврило Витковић у Гласнику Српског ученог друштва из 1872. године (Томин 2007: 143), наводећи као разлог публиковања то што је Венцловићев текст написан по предању, те се разликује од текста објављеног у Србљаку (Витковић 1872: 157).

7 У питању је рукопис Изабране службе свециима, који се чува у Архиву САНУ под редним бројем 28 (142).

${ }^{8}$ Гаврило Витковић (1872: 162) скреће пажњу на ову епизоду указујући на њену нетачност, а разлоге оваквој Венцловићевој интерпретацији тражи у његовом заштитничком ставу према калуђеру Максиму, којег је Змај Огњени Вук, наводно, омрзнуо јер се покалуђерио у време када да је требало да мачем брани свој народ. Светлана Томин (2007: 150) доказује неверодостојност ове тврдње, указујући да је Змај Огњени Вук умро пре доласка деспота Ђорђа у Срем и његовог замонашења. 
препису Пролошког житија Светог Максима Бранковића, писаном у основи народним језиком.

Допунским клаузалним структурама сматрамо оне којима се употпуњава, односно конкретизује садржај управне речи: а) глагола, б) безличног глаголског израза, в) именице и г) придева. Међу њима разликујемо вербална и номинална средства. Вербална средства представљају зависне допунске реченице, а номинална обухватају инфинитиве и инфинитивне конструкције (нпр. датив + инфинитив и акузатив + инфинитив), као и конструкције двоструки акузатив и акузатив с партиципом (герундом) као његовом подврстом. Многа вербална и номинална средства, заправо, представљају конкурентна средства за исказивање истог пропозитивног садржаја, а њихов однос указује на стил изражавања - доминантнија употреба вербалних средстава упућује на приближавање стила говорним обрасцима, док употреба номиналних средстава представља одлику вишег, књишког стила изражавања. Међу номиналним средствима срећемо структуре које су истовремено одлика и народног и књижевног језика као и оне које, као наслеђене из српскословенског језика, представљају књишке конструкције. ${ }^{9}$

У тексту Пролошког житија Светог Максима Бранковића у функцији допуне забележена су и вербална и номинална средства. Вербалним структурама допуњавало се место субјекта, објекта или предикатива у аргументској структури главног реченичног предиката. У овом раду нисмо се бавили глаголским одредбама адвербијалног типа будући да је овој теми посвећена посебна студија (Colić 2017).

Ексцерпирана грађа класификована је најпре на допуне у функцији објекта и оне у функцији субјекта да би у оквиру њих била детаљније сагледавана са синтаксичко-семантичког аспекта. У оквиру сваке синтаксичко-семантичке позиције праћена је конкурентна употреба номиналних и вербалних средстава којима се исказивао исти пропозитивни садржај, као и то да ли постоји разлика на семантичком плану међу њима. Пратећи конкурентни однос међу вербалним и номиналним средствима, покушали смо да откријемо који тип допуне доминира у језику Гаврила Стефановића Венцловића и које се структуре могу сматрати књишким

9 О статусу номиналних конструкција у српскословенском језику за изражавање допунског реченичног садржаја в. у Курешевић 2015. 
конструкцијама (црквенославенизмима), а које имају вернакуларни карактер, како бисмо на основу добијених резултата одредили стил језика којим је писано Пролошко житије Светог Максима Бранковића.

\section{4. Теоријски оквири}

Однос вербалних и номиналних средстава посматрали смо у светлу језичке еволуције током које је, као последица нарастајуће синтаксичке транзитивности, ${ }^{10}$ долазило до вербализације језика, тј. до замене номиналних средстава за исказивање семантичке субординације вербалним структурама и до формирања зависносложене реченице уведене новим типовима везника. Стога смо поред односа употребљених вербалних и номиналних средстава у овом раду пратили и типове везника којима су се уводиле зависносложене реченице будући да су и они показатељи степена развијености језика, односно хипотаксе. Описани процес је нарочито долазио до изражаја у говорном језику, док је књижевни језик могао да чува номинална средства и везнике пореклом из књишког лексичког регистра као одлику вишег стила изражавања.

${ }^{10}$ Крајем праиндоевропске епохе долази до промена у дубинској структури језика, које утичу на промену типа језика: од језика активно-инактивног типа, тематски оријентисаног, какав је био праиндоевропски, индоевропски језици се развијају ка номинатвно-акузативном типу, агентивно оријентисаном, што ће оставити трага на морфолошком, синтаксичком, али и лексичком плану ових језика. Главном манифестацијом ове промене сматра се развој синтаксичке транзитивности која води ка формализацији субјекатско-објекатских односа у реченици, што даље води до стварања нових синтаксичких структура у овим језицима. С развојем синтаксичке транзитивности, реченични предикат добија најважнију улогу у интеграцији реченице, те се реченица централизује око њега што је водило ка формирању сложених реченица. С повећањем међуреченичне кохезије долази до реанализе ранијих паратактичких структура, те се из простијих структура развијају сложеније, али и до другачијег енкодирања дубинских хипотактичких структура исказаних номиналним средствима. У том процесу многа номинална језичка средства замењују се вербалним, чиме се постиже прецизирање субјекатско-објекатских односа будући да су номинална средства семантички дифузна (уп. нпр. ГрковићМејџор 2007: 77-98). Појава замене инфинитива везом дa + презент у балканским језицима пример је овакве „вербализације” језика, односно потврда преласка језика с номиналног на вербални тип. Реанализа паратактичких структура подразумева и граматикализацију пунозначних речи (упитних речи, деикси и партикула) и конектива у везнике. 


\section{5. Анализа}

\section{1. Клаузалне структуре у функцији објекта}

\subsection{1. Допуне модалним и фазним глаголима}

Модалним глаголима припадају глаголи непотпуног значења којима се исказују значења могућности, неопходности или допуштања, а који са својом семантичком допуном пропозитивног садржаја ступају у таутосубјекатске односе. Модалним глаголима се може исказивати: а) динамичка (објективна или субјективна могућност) или б) деонтичка модалност (неопходност и допуштање). ${ }^{11}$ Модалним глаголом моћи у нашем корпусу исказивана је динамичка модалност, док су модално употребљеним глаголом имати могле бити исказане и динамичка и деонтичка модалност, при чему је у случају деонтичке модалности његова употреба секундарна. Уз модалне глаголе је доследно забележен таутоагентивни инфинитив (7x) као допуна реченичног садржаја:

а) динамичка модалност

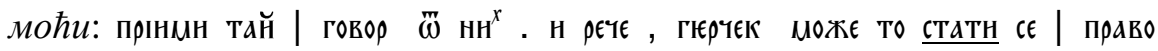

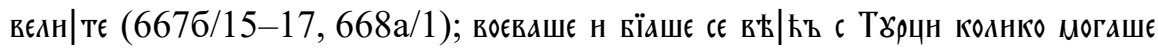

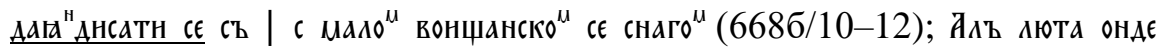

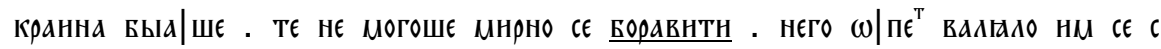
Т૪рцн Харцатн , н

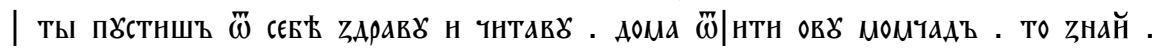

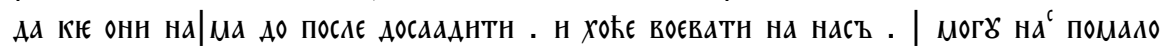

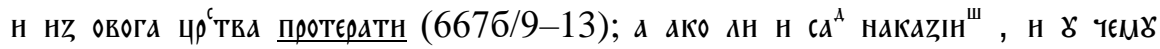

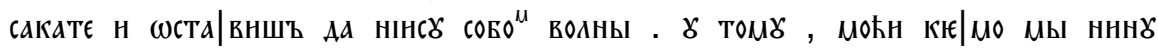

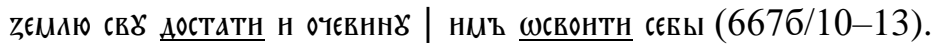

\footnotetext{
${ }^{11}$ Иако се волунтативни глаголи, којима се означава исказивање жеље, такође могу сматрати модалним глаголима, ми ћемо их разматрати посебно будући да на синтаксичном плану испољавају извесне специфичности у односу на остале глаголе из групе модалних глагола.
} 
имати (у значењу 'моћи, бити у могућности'): Нндн що да чнны

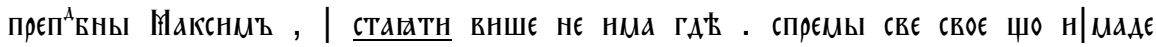
(671a/6-8).

б) деонтичка модалност

имати (у значењу 'требати'): Пнса

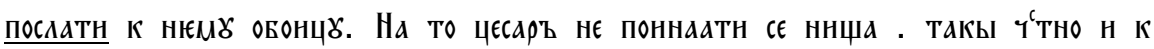
нещ૪ с пீщенеє посла (669б/11-14).

Фазни глаголи су, такође, глаголи непотпуног значења и њима се означавају различите фазе процеса означеног допунским пунозначним глаголом. Фазни глаголи увек стоје у таутосубјекатском односу с глаголом допунског пропозитивног садржаја, те не чуди што је у нашем корпусу инфинитив (9x) доследно употребљен као допуна фазних глагола. Од фазних глагола у тексту забележени су глагол почети и глагол узети у истом значењу:

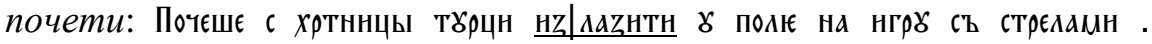
нгратн сє | џнАнта, стрєАґа|Тн птнцє. н оүтркаватн | сє на конн, на бГАє тко є Бржы $(667 \mathrm{a} / 19-21,6676 / 1-2)^{12}$; По Бра ${ }^{\mathrm{T}}$ нішн̆ смртн . н ако Є н КаАУГЕръ . Почє Га КаАнНТН Кра

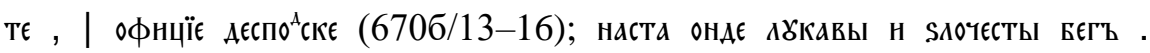

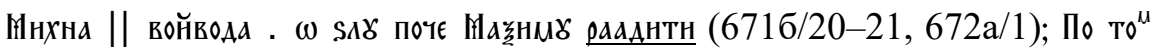

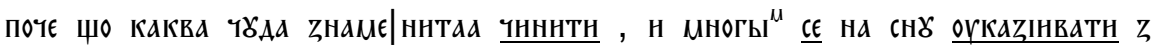
Бєсє| АО

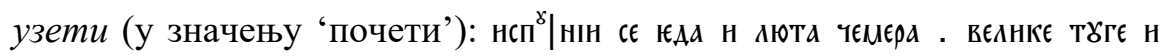
жало"|Тн. бZє набкатн н Плакатн єцаюћн дератн | сє горко (668a/7-10); Н оүZє

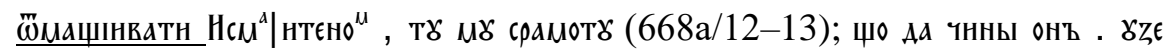

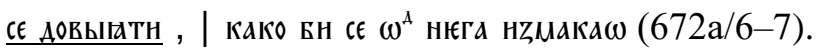

\footnotetext{
12 У овом примеру само први инфинитив се налази у функцији допуне главног реченичног предиката, док се остали инфинитиви који следе за њим (играти се, стрељати, уткривати) налазе у функцији адвербијалне одредбе са значењем намере.
} 


\subsection{2. Допуне волунтативним глаголима}

Инхерентна семантичка компонента волунтативних глагола јесте исказивање жеље, воље или намере. Будући да се код ових глагола субјектова воља може усмерити и на сопствену и на туђу радњу, у случајевима једнакости субјеката главне и зависне предикације очекивана допуна је инфинитив, док се замена инфинитива конструкцијом $\partial a+$ презент у овим ситуацијама сматра редундантном. С друге стране, при неједнакости субјеката главне и зависне предикације неопходно је направити диференцијацију субјеката употребом конструкције $\partial a+$ презент.

У тексту Пролошког житија из ове синтаксичко-семантичке класе глагола забележене су лексеме хтети и зажелети. Уз њих се у функцији семантичке допуне могао наћи а) инфинитив (4x) и б) зависна реченица (4x), и у једном и у другом случају доследно у таутосубјекатским структурама:

\section{а) инфинитив}

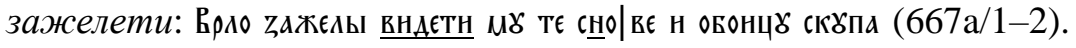

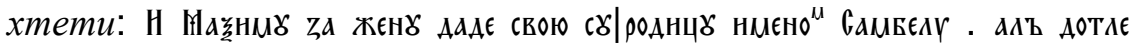

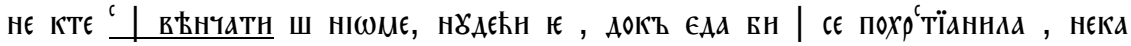

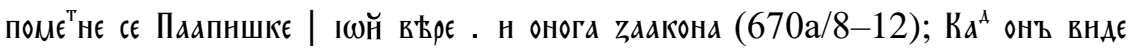

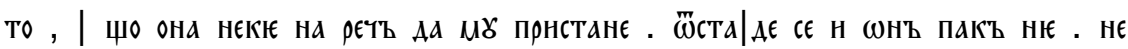
кте є zаa се Паапн" "ко" | огZетн (670a/13-16); $\omega$ цару тестнты . ако | ты

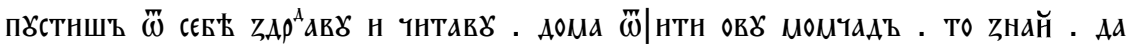

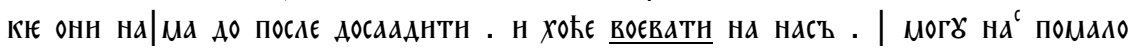
н НZ овога цр тва протератН $(6676 / 9-13)$.

б) зависна реченица

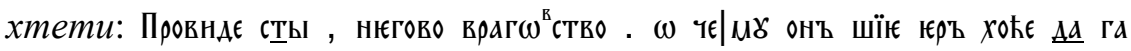

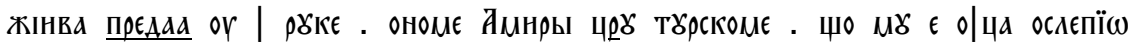

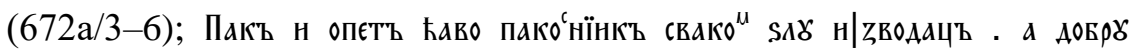

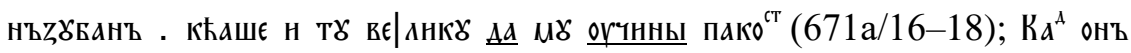

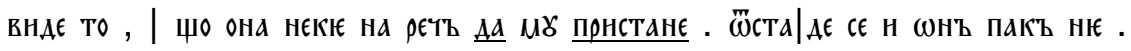
не кте є zаa се Паапн"ко" | оүZетн (670а/13-16); Провнде сты , негово

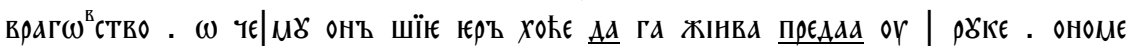

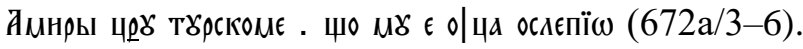




\subsection{3. Допуне когнитивним глаголима}

Когнитивним глаголима припадају они глаголи чији се пропозитивни садржај презентује као спознаји доступна чињеница (Павловић 2009: 27). ${ }^{13}$ Ови глаголи пресупонирају фактивност пропозиције исказане допуном, односно потпуну сигурност у њену истинитост (Грковић-Мејџор 2018: 90). У нашем тексту од когнитивних глагола у позицији управног предиката забележени су глаголи знати, разабрати и провидети.

Уз когнитивне глаголе у нашем тексту нису потврђене номиналне допуне, што смо тумачили инхерентном семантиком забележених когнитивних глагола, којом се упућује на увереност у истинитост пропозитивног садржаја будући да је у семантичком потенцијалу когнитивних глагола присутно обележје фактивности. Као реченице у функцији допуне уз когнитивне глаголе забележене су зависно-изјавне, односно асертивне допунске реченице уведене везницима да (3x), како (1x) и јер (1x), и зависно-упитна, односно дубитативна допунска реченица уведена заменицом ита у локативу (1x) у функцији везника. Све забележене допуне налазе се у хетеросубјекатском односу с главном реченичном предикацијом:

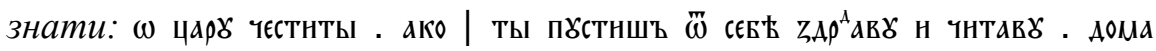

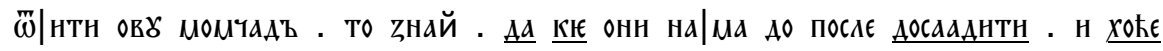
воєватн на насъ . | могб нас помало н нZ овога црства протератн (667б/9-13).

У наредном примеру јавља се кореферентна конструкција с деиктиком коју допунска (експликативна) реченица садржински разјашњава. Заменица у функцији деиктике служи као наслон односно пилон за реченичну конструкцију с којом је у „пунктуалном” додиру (Грицкат 2004: 79). Истакнути именски изрази (заменице или именице) у функцији кореферента информацијски су редундантни, а често и граматички необавезни реченични чланови, али је њихова комуникативно-стилистичка улога неоспорна (Ружић 2006: 110). У оваквим структурама, када долази до удвајања номиналних и

\footnotetext{
${ }^{13}$ Когнитивни глаголи су само део групе глагола менталних манифестација, којима припадају још глаголи мисаоног ишчекивања (експектативни) и глаголи одлучивања (декретивни). Будући да ове две групе глагола нису забележене у нашем корпусу, у раду смо се бавили само когнитивним глаголима.
} 
реченичних допуна, међу суседним предикацијама успоставља се лабавији синтаксичко-семантички однос кооптације (Курешевић 2014: 236):

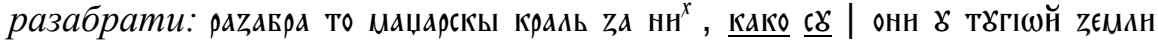
снро Нн | Бїнху , за женнАББ скоро (669б/8-11).

Интересантна је употреба везника јер у наредном примеру: чини се да се у њему преплићу декларативна и узрочна семантика, што не чуди будући да имају исто порекло. ${ }^{14}$

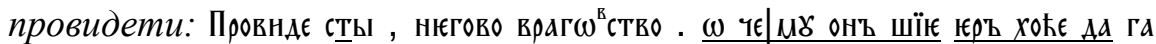

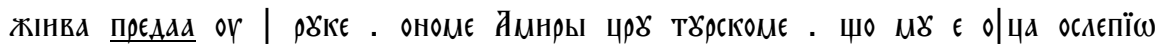
$(672 \mathrm{a} / 3-6)$.

\subsection{4. Допуне глаголима перцепције}

Глаголи перцепције се према типу рецептора деле на глаголе визуелне перцепције, глаголе аудитивне перцепције и глаголе тактилне перцепције. Ови глаголи увек реферишу о домену реалног, те је очекивано да се њихов пропозитивни садржај исказује средствима којима се упућује на фактивност, док уз њих не очекујемо инфинитив, који због свог порекла увек упућује на субјунктивну сферу.

Као допуна глаголима перцепције у нашем тексту од вербалних средстава потврђена су само три примера реченичне допуне уведене везником да и uто уз глагол визуелне перцепције (видети), ${ }^{15}$ којим се исказивало значење

\footnotetext{
${ }^{14}$ О овом поклапању семантичког поља декларативности и каузалности, које је било типично и за раније епохе српског језика, али и за грчки и латински језик, писала је Ирена Грицкат (2004: 150-151). Разлоге за обликовање изричних реченица узрочним везницима ауторка види у прелазним узрочно-изричним реченичним ситуацијама.

15 Иако у нашим примерима забележени глагол визуелне перцепције метафоризацијом поприма значење когнитивног глагола спознати / увидети / схватити, те се њиме исказује ментална перцепција (знање стечено на основу перцептивног искуства), сврстали смо га у перцептивне будући да се на синтаксичком плану понаша као такав.
} 
индиректне евидентности. Посебно је интересантан пример с везником што будући да у нашој историјској грађи нису нађени примери за изрично што (Грицкат 2004: 153, Грковић-Мејџор 2018: 98), мада се остаци ове употребе чувају у неким дијалектима. ${ }^{16}$ Употреба везника што у овом примеру уноси семантику фактивности, тј. радње која се десила. Будући да се и управни глагол који допуњује реченица уведена везником што налази у склопу ширег реченичног комплекса као део временско-узрочне реченице уведене везником кад, која се поима и као узрок главне предикације, могуће је да је писар употребом допунског везника што у овом примеру хтео да додатно нагласи њену узрочну семантику:

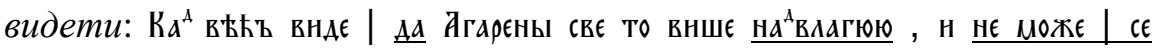

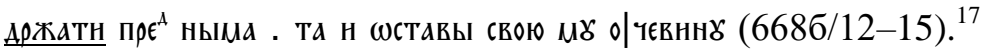

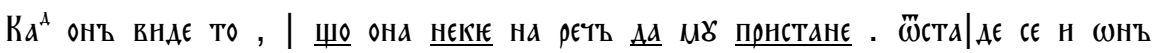
пакъ ніе. не кте є zаa се Паапн"ко" | оүзетн (670a/13-16).

Кореферент то у другом примеру може да сведочи о несамосталности, односно о непотпуној граматикализацији везника што у овој функцији. Допунска (релативна) реченица се у овим ситуацијама понаша као семантичка спецификација показне заменице у функцији деиктике из главне реченице. Овај образац је потврђен у раним фазама индоевропског језика. Следећи стадијум је уклањање деиктике и реанализирање допунске (релативне) реченице у објекатски аргумент (Cristofaro 2003: 97 према Грковић-Мејџор 2018: 93). Ове структуре карактеристичне су за говорни језик (Грковић-Мејџор 2018: 94), а у савременом стандардном српском језику уз глаголе говорења, мишљења и опажања сматрају се стилски маркираним средствима (Ружић 2006: 112).

\footnotetext{
16 Ирена Грицкат (2004: 154) употребе везника што у изричној функцији у књижевном делу Ивкова слава карактерише као имитацију призренско-тимочког говора, а помиње и да се допунско што одржало и у говору Галипољских Срба.

17 У овом примеру, у оквиру једне сложене реченице јављају се две допунске реченице на дубинском нивоу субординиране главној реченици, које стоје у напоредном односу. У оквиру друге реченице изостављен је (претпостављени) везник $\partial a$, што се може тумачити стилским разлозима - избегава се понављање истог везника.
} 
Остали примери реченичних допуна глаголима визуелне и аудитивне перцепције, ${ }^{18}$ уведени заменицом ито у функцији везника, представљају граничне случајеве између допунских и релативних реченица при чему се, због употребе кореферента, у оваквим случајевима предност даје релативној реченици. ${ }^{19}$ Због своје фазичне семантике, ове примере нисмо убројали међу примере реченичних допуна перцептивних глагола:

а) визуелна перцепција

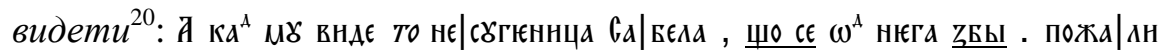
н раскаға се $\omega$ томе чо иљ по ћбдн не по|ге (670а/19-20, 670б/1-3).

б) аудитивна перцепција

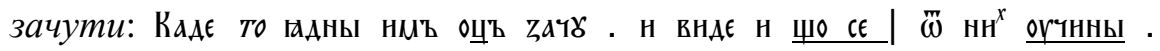

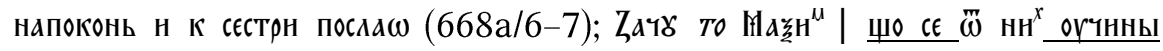
$(6726 / 2-3)$.

Од номиналних средстава забележена су два примера конструкције двоструког акузатива ${ }^{21}$ уз глаголе гледати и видети, од којих је једна конструкција акузатив + герунд:

а) двоструки акузатив

\footnotetext{
18 Допуне глагола тактилне перцепције нису забележене у анализираном тексту.

19 Владислава Ружић за савремени српски језик констатује следеће: „У свим примерима (ко)релативно-објекатских клауза анафорска реч заједно с конјукцијом уводи зависну клаузу, а њен садржај надокнађује зависна предикација која служи као својеврсни детерминатор атрибутског типа и њен смисаони конкретизатор." (Ружић 2006: 64).

20 У оба наведена примера глагол видети има значење когнитивног глагола.

21 Први елемент ових конструкција (именска реч у акузативу) који, по правилу, представља појам с обележјем живо +, има функцију објекта управног глагола, док други елемент има функцију предикативног атрибута, којим се исказују особине појма у позицији објекта попут стања, изгледа, положаја и сл.
} 


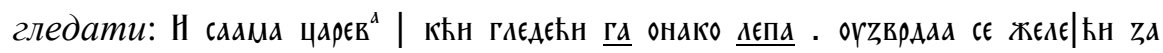
нН $^{\prime \prime}$. н радгаше

б) конструкција акузатив + герунд

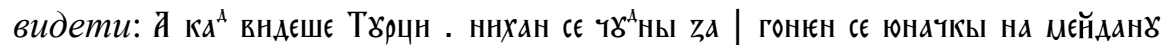

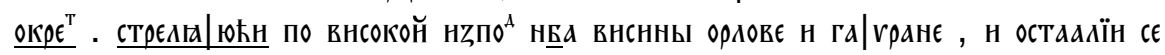

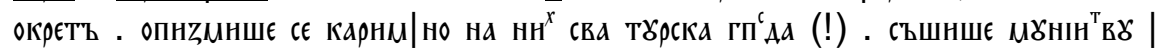
МеГю соБо ${ }^{\mathrm{M}}(6676 / 3-8)$.

\subsection{5. Допуне комуникативним глаголима}

Комуникативне глаголе делимо на две семантичке подгрупе: глаголе говорења референцијалног карактера и јусивне глаголе, који у свом семантичком потенцијалу садрже модалну нијансу и којима се исказује молба, захтев или наредба.

У тексту Пролошког житија зависна реченица уз комуникативне глаголе могла је бити уведена везницима да, како и нека при чему изрично како, наследник старословенског јако, када се јавља у изричној, допунској функцији, у себи носи нијансу описног изражавања (Грицкат 2004: 145).

Допуна комуникативним глаголима референцијалног карактера могла је да буде и у таутосубјекатском и у хетеросубјекатском односу с главним предикатом, док је допуна јусивних глагола с главним предикатом формирала хетеросубјекатску реченичну структуру. Као семантичка допуна комуникативним глаголима референцијалног карактера зависна реченица се јављала у 8 примера (а), док је уз јусивне глаголе забележена у само 1 примеру (б):

a) зависна реченица уз комуникативне глаголе референцијалног карактера peћu: Н тако бстаде. WстаaAo $\Psi^{\circ} \mid$ І

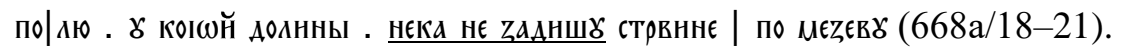




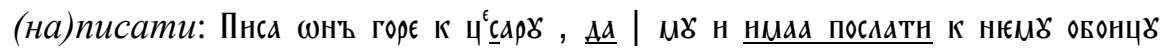

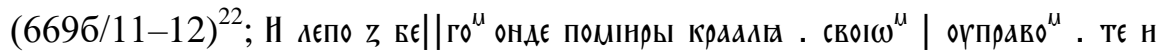

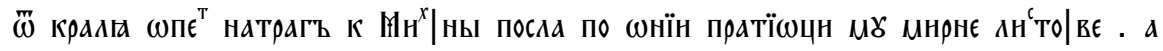

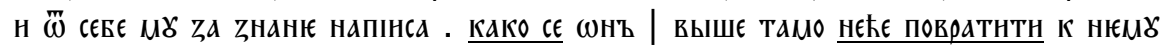
, на свою | М૪ мнтрополїю. нєка посталғаю, кога Фнн | хоћє $\bar{\omega}$ вншє $(672 \mathrm{a} / 21$, $6726 / 1-7)$.

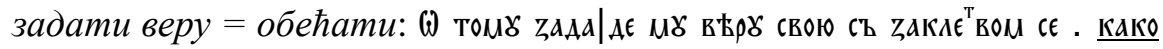
ћє н | онъ Пакъ на скоро. ч'тно с пощєне дома. н послатн | н к своМе оцб мнрно (667a/5-9). ${ }^{23}$

б) зависна реченица уз јусивне глаголе

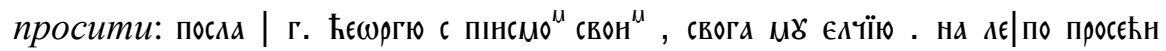
сє. да М૪ н пошАЕ (!), н нно не бчнны (667a/2-4).

Забележен је и значајан број јукстапонираних реченица којима се исказивао директни говор, које су биле доминантно средство за исказивање изреченог садржаја. Овим конструкцијама постиже се приближавање нарације обрасцима својственим усменом говору:

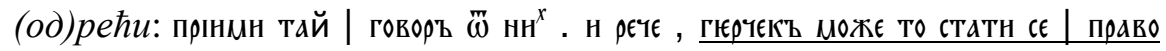

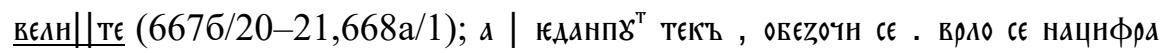

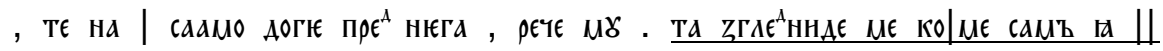

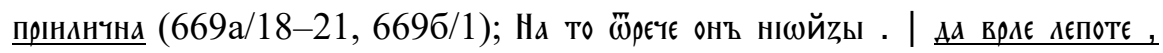

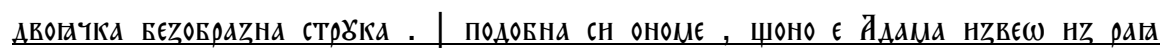
(669б/1-3); Пакъ запнта онІн що око | нега стонаху . рече нМъ Браћо доБра.

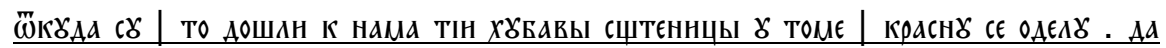

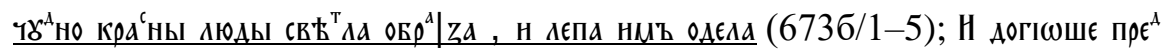

22 Овако употребљен глагол писати може се тумачити и као каузативни глагол будући да се у својству волунтативно-директивне предикације често јављају информативно-констативни и информативно-комисивни глаголи (Павловић 2009: 53).

${ }^{23}$ Овај пример је потврда замене инфинитива субјунктивног карактера допунском реченицом с предикатом у футуру. 


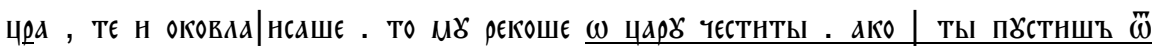

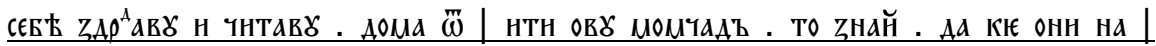

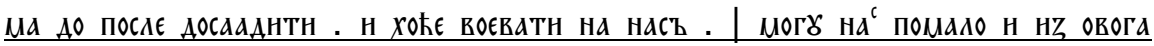
цр Тва ПротератН $(6676 / 8-13)$.

У нашем тексту нису забележени примери зависног директног говора с партикулом која најављује директни говор попут оне тзв. jako recitativum у старословенским или редакцијским споменицима, којима се ублажава прелаз између нараторовог текста и исказа актуелног говорника. ${ }^{24}$

Инфинитив је забележен само уз јусивне глаголе (3x). Потврђене инфинитивне допуне јусивних глагола увек се налазе у хетеросубјекатском односу с глаголом главне реченице: агенс инфинитивне радње налази се у кореферентном односу с индиректним објектом управног глагола, који је у забележеним примерима могао бити у дативу и акузативу. У једном примеру агенс инфинитивне радње је уопштен. Употребом инфинитива уз овај тип глагола означава се субјунктивни карактер глаголске допуне (Курешевић 2014: 84):

Заповедити: ҚаПовєдын | БарБнрУ . ПрєсєћН нМъ очне жнАє (668a/3-4);

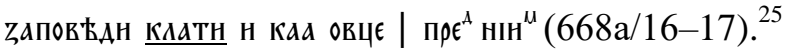

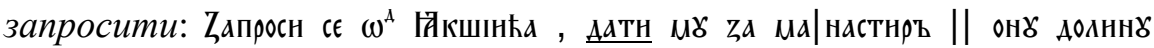
$(6726 / 20-21,673 a / 1)$.

\subsection{6. Допуне каузативним глаголима}

Под каузативним глаголима смо подразумевали глаголе сложене рекције којима се исказује дозвола или забрана, као и глаголе којима се чини да ко (не) учини што или да (не) буде / постане што. Главна карактеристика каузативних глагола је да се на синтаксичком плану између њих и њиховог пропозитивног садржаја успостављају хетеросубјекатски односи, повезани

\footnotetext{
${ }^{24}$ У науци је прихваћен став да везник јако у овим, асиндетским, допунама не треба сматрати изричним везником, већ речцом са семантиком скретања пажње на оно што се даље износи ('гле'). Исто вреди и за изрични везник јеже (>јере) у оваквим структурама. Ова појава забележена је и у класичним језицима (Грицкат 2004: 147). ${ }^{25}$ Пример с уопштеним агенсом зависне предикације.
} 
преко кореферентних денотата, што значи да је субјекат допунског садржаја истовремено (ин)директни објекат управног глагола (Курешевић 2014: 76). Као допуна каузативним глаголима потврђена су и вербална и номинална средства: а) зависна реченица уведена партикулом нека у функцији везника $(3 x)$, б) инфинитив $(2 x)$ и в) двоструки акузатив $(1 x)$ :

а) зависна реченица

послати: посла н нека слоБо нагледа ${ }^{\text {ю }}$, | Кћєр М૪ . свою ниъ сестрУ (667a/10-12).

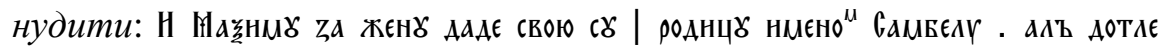
некте '

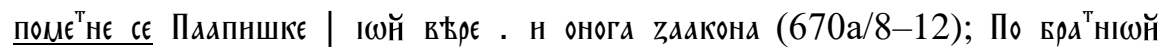

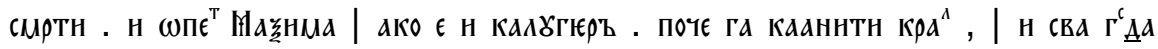

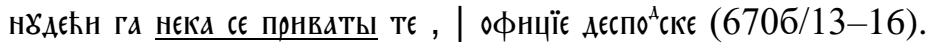

б) инфинитив

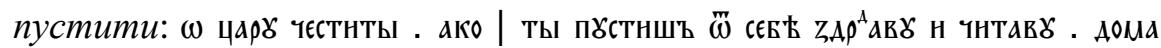

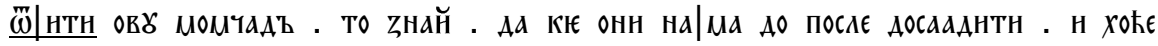
воєватн на насъ . | МогУ на' поМало н нҚ овога цр' ТЕа Протератн (667б/9-13).

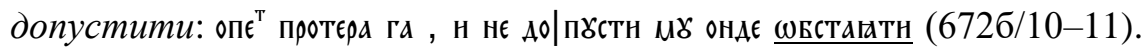

в) двоструки акузатив

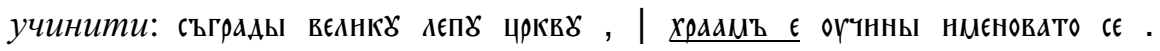

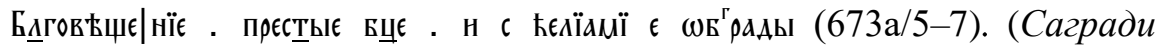
велику лепу цркву, учини је храмом...).

\section{2. Клаузалне структуре у функцији субјекта}

Посматрано с формалног, тј. синтаксичког аспекта, зависна допунска реченица може се наћи и у позицији субјекта. Субјекатске реченице у функцији семантичке допуне предикатских израза, иако се на формалносинтаксичком плану налазе на позицији субјекта, на семантичком плану репрезентују објекат или посебне типове субјекатског аргумента (Ружић 
2006: 84). Ове реченице понашају се као комплементи главне предикације чију семантику експлицирају, а која им својом имперсоналном формом омогућава субјекатски статус (Ружић 2006: 84).

У старосрпској писмености потврђено је више типова имперсоналних реченица које су могле да попуњавају позицију субјекта: (негиране) егзистенцијалне реченице, реченице с предикативом, реченице с пасивним партиципом презента / претерита, реченице с безличним глаголима, реченице с морфемом се уз нерефлексивне глаголе и реченице с глаголом вытн и инфинитивом (уп. Грковић-Мејџор 2007: 188-203).

У тексту Пролошког житија у функцији субјекта забележени су примери a) инфинитива с дативом (3x) и б) допунске реченице (1x). У првом случају то је био низ инфинитива у својству семантичке допуне безлично употребљеног глагола ваљати којим се исказује модално значење. Појаву датива уз инфинитив у својству допуне дате имперсоналне конструкције тумачимо потребом за истицањем агенса инфинитивне радње будући да је он у датом примеру спецификован, тј. није уопштен. ${ }^{26}$

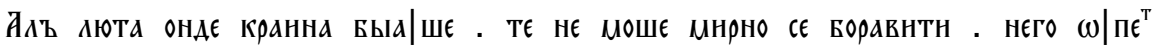

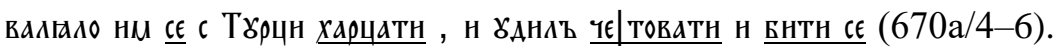

У другом забележеном случају у функцији субјекта уз рефелексивно употребљен глагол из групе dicendi забележили смо, поред именице чъА0, и допунску експликативну реченицу уведену везником $\partial a$ :

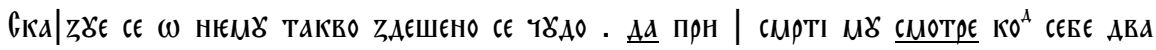

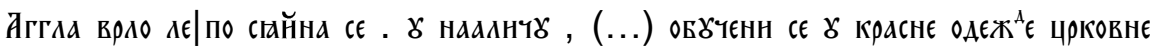
(673a/15-20).

У наведеном примеру комбинују се номинална и реченична допуна: синтагма такво здешено чудо и допунска реченица уведена везником $\partial a$.

\footnotetext{
${ }^{26}$ Уколико агенс инфинитивне радње није конкретизован, већ уопштен, као допуна глаголу главне предикације стајаће само инфинитив (Грковић-Мејџор 2007: 195).
} 
Појаву допунске реченице у овим случајевима Владислава Ружић (2006: 111) тумачи као потребу за конкретизовањем објекатског садржаја исказаног именицом с апстрактним, неодређеним значењем, а понекад се реченичном допуном постиже и експлицирање новог, другачијег, неочекиваног смисла. Уз то, овакво удвојено појављивање номиналних и реченичних допуна уз исте управне речи често је и стилистички обележено.

\section{6. Закључна разматрања}

Анализом клаузалних структура у функцији допуне у Пролошком житију Светог Максима Бранковића Гаврила Стефановића Венцловића закључили смо да је тип допунског пропозитивног садржаја у великој мери зависио од синтаксичко-семантичких карактеристика управних речи.

Реченице фигурирају као допуне комуникативним, когнитивним, каузативним, перцептивним, чак и волунтативним глаголима, док се уз модалне и фазне глаголе, који захтевају искључиво таутосубјекатске односе, појављивао искључиво инфинитив у функцији допуне.

Уз когнитивне глаголе доследно је забележена допунска реченица асертивног типа уведена везницима $\partial a, j e p$ и како. Исти тип реченице уведен везницима $\partial а$ и што јавља се уз глаголе перцепције (у 60\% случајева). У функцији допуне комуникативним глаголима референцијалног типа доследно је забележена зависна реченица, док је уз јусивне глаголе зависна реченица заступљена у свега $25 \%$ примера. Јукстапонирани директни говор, у чијој се употреби огледа приближавање вернакуларном стилу изражавања, чини трећину свих забележених примера с комуникативним глаголима.

Допунска реченица дубитативног типа забележена је у само једном примеру, уз когнитивни глагол, док је допунска реченица волунтативног типа забележена у 3 примера, уз глаголе послати и нудити, који припадају семантичкој групи каузативних глагола.

Инфинитив као семантичка допуна доследно је потврђен уз модалне и фазне глаголе с којима ступа у таутосубјекатске односе. Уз волунтативне глаголе, који су такође ступали са својом семантичком допуном у таутосубјекатске односе, инифнитив је забележен у подједнаком односу као и реченица. Осим тога, инфинитив је очуван и уз оне глаголе с којима гради хетероагентивне структуре, ступајући с њима преко заједничких денотата у 
јаке синтаксичке везе: уз каузативне $(33,3 \%)$ и јусивне $(75 \%)$ глаголе. Овакве употребе инфинитива су општесловенског карактера.

Од номиналних средстава у овом функционално-семантичком пољу, поред инфинитива, забележена је у једном случају конструкција акузатив + герунд уз перцептивне глаголе, као и по један случај конструкције двоструког акузатива уз перцептивне и каузативне глаголе.

Употреба конструкције акузатив + герунд, односно допунске реченице уз глаголе перцепције зависи од семантичког фактора, порекла информације да ли се информација добија из личног или туђег искуства. Конструкцијом акузатив + герунд се уз перцептивне глаголе исказивала директна евиденцијалност што значи да се до информација дошло из личног искуства. C друге стране, вербалном структуром се уз исте глаголе исказује индиректна евиденцијалност што значи да се до информација дошло из туђег искуства. Конструкција с двоструким акузативом представља траг архаичног стања у језику и потврђена је и у ранијим фазама српског језика, док се конструкција акузатив + герунд, иако подврста двоструког акузатива, као номинално средство у народном језику рано почела замењивати вербалном структуром (уп. Grković-Mejdžor 2018), док се у књишком сачувала као стилска одлика књижевнојезичког начина изражавања.

Од забележених употреба номиналних средстава у нашем корпусу, закључујемо да преовлађују таутоагентивни и хетероагентивни инфинитив, а да се у свега три примера јављају двоструки акузатив и конструкција акузатив + герунд, средства која, иако имају прасловенско порекло, представљају архаичну црту.

Ако упоредимо резултате до којих смо дошли у нашем истраживању с резултатима истраживања хипотактичких структура у адвербијалној употреби на истом корпусу, до којих је дошла Александра Цолић (2017), уочавамо сличности које помажу при дефинисању стила Венцловићевог језика.

Ауторка закључује да је у свим пољима адвербијалне употребе у којима је била могућа конкуренција зависне клаузе и герунда убедљиво доминирала употреба зависне клаузе, као вернакуларног средства, у односу на употребу герунда, као књишке црте, која је половином XVIII века увелико у процесу повлачења из говорног језика. С друге стране, забележена је доминантнија употреба инфинитива (у односу 2:1) у односу на зависну клаузу уведену 
везником да у функционално-семантичком пољу намере. Као и у функцији допуне, и у адвербијалној функцији забележена је употреба инфинитива и у хетеросубјекатским структурама када се субјекатски конституент експлицира именском речи у дативу (а иста појава је забележена и уз герунд презента са значењем пратеће околности). Појава датива се у овим ситуацијама сматра утицајем књишког језика будући да на овај начин настају конструкције налик на архаичну конструкцију датив + инфинитив, које и ми бележимо у нашој грађи (уп. нпр. Н тай мнръ | Аоконаа н оүтврды мєћъ нVма .

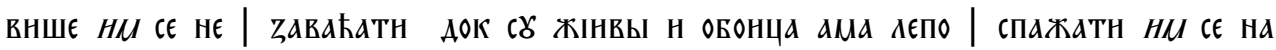

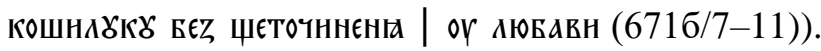

На основу изнетих чињеница закључујемо да су номинална средства у тексту Пролошког житија Светог Максима Бранковића очувана у оним употребама које представљају прасловенско наслеђе и које су истовремено одлика књишког и говорног језика, док је употреба књишких средстава (у овом случају конструкције двоструког акузатива и акузатив + герунд) сведена на минимум. На плану реченице потврђени су једино везници новог типа (изведени од $* k$ - основа) којима се семантички прецизира пропозитивни садржај.

Утицај српскословенског на Венцловићев народни језик у овом домену језичког система могуће је видети у фреквентнијој употреби инфинитива у односу на допунску клаузу уведену везником $\partial a$ уз јусивне глаголе, као и у присуству архаичних, књишких средстава попут конструкција двоструког акузатива и акузатив + герунд, што у резултату даје специфичну стилизацију Венцловићевог језичког израза.

\section{ИЗ В О Р}

Пролошко житије Светог Максима Бранковића у саставу рукописа Житија, слова и поуке разних светих (666а-674a), Архив САНУ 84 (270).

\section{ЛИТ Е Р А Т У Р А}

Богдановић, Димитрије (1991). Историја старе српске књижевности, Београд: Српска књижевна задруга.

Витковић, Гаврило (1872). О књижевном раду јеромонаха Гаврила Стефановића. Гласник Српског ученог друштва, књ. XXXIV: 151-177. 
Вукомановићъ, Алекса (1859). Животъ архиепископа Максима. Изъ рукописа XVII века кои е у подписанога. Гласникъ друштва србске словесности, књ. IX: $125-129$.

Грицкат, Ирена (2004). Студије из историје српскохрватског језика. Београд: Народна библиотека Србије.

Грковић-Мејџор, Јасмина (2007). Списи из историјске лингвистике. Сремски Карловци - Нови Сад: Издавачка књижарница Зорана Стојановића.

Грковић-Мејџор, Јасмина (2018). Развој клаузалне допуне когнитивних предиката у српском језику. У: Српска славистика : колективна монографија (радови српске делегације на XVI међународном конгресу слависта), том 1, Језик (ур. Р. Драгићевић, В. Брборић). Београд: Савез славистичких друштава Србије: 173-188.

Гроздановић-Пајић, Мирослава (1992). Хартија и водени знаци у Венцловићевим рукописима писаним у Коморану и Ђуру. Сентандрејски зборник, 2: 177 179.

Јовановић, Владан (1911). О језику Гаврила Стефановића Венцловића, Дијалектолошки зборник Српске краљевске академије, 2: 105-306.

Курешевић, Марина (2014). Хипотактичке структуре у Српској Александриди: функиионалностилски апсекти. Нови Сад: Филозофски факултет.

Курешевић, Марина (2015). Проучавање хипотактичких структура и њихова улога у расветљавању функционалностилске раслојености српскословенског језика. У: Српски језик и юегове норме: дијахроно-синхрони аспекти. Ед: Лингвистичке свеске (ур. Ј. Грковић-Мејџор, В. Ружић). Нови Сад: Филозофски факултет, Одсек за срспки језик и лингвистику: 64-82.

Новаковић, Стојан (1904). Примери књижевности и језика старога $u$ српскословенскога, Београд.

Павић, Милорад (1966). Црни биво у сриу: легенде, беседе, песме, Београд: Просвета.

Павић, Милорад (1972). Гаврил Стефановић Вениловић, Београд: Српска књижевна задруга.

Павић, Милорад (1991). Историја српске књижевности 2: барок. Београд: Досије, Научна књига.

Павловић, Слободан (2009). Старосрпска зависна реченица, од XII до XV века. Сремски Карловци - Нови Сад: Издавачка књижарница Зорана Стојановића.

Ружић, Владислава (2006). Допунске реченице у савременом српском језику. Нови Сад: Матица српска.

Стојановић, Љубомир (1901). Каталог рукописа и старих штампаних књига. Збирка Српске краљевске академије. Београд.

Томин, Светлана (2007). Владика Максим Бранковић. Нови Сад: Платонеум.

Colić, Aleksandra (2017). Hipotaktičke strukture adverbijalnog tipa u Venclovićevom Prološkom žitiju Svetog Maksima. Romanoslavica, LIII/1: 13-30.

Grković-Mejdžor, Jasmina (2018). The development of perception verb complements in the Serbian language. (eds. J. Grković-Major, B. Hansen \& B. Sonnenhauser). Diachronic Slavonic Syntax. The Interplay between Internal Development, 
Language Contact and Metalingistic Factors. Berlin - Boston: de Gruyter, 339360.

\section{Sanja Petrović}

COMPLEMENT CLAUSE STRUCTURES IN THE VITA OF HOLY MAKSIM BRANKOVIC BY GAVRIL STEFANOVIC VENCLOVIC FROM 1744/1755

\section{SUMMARY}

The topic of this paper is the syntactic and semantic analysis of complement clause structures (both verbal and nominal ones) in Prološko žitije Svetog Maksima (The Vita of Holy Maksim) written by Gavril Stefanović Venclović. The sources were digital photographs of Venclović's autograph from 1744/45, Archives of SASA, 84 (270). A detailed qualitative and quantitative analysis were conducted and the results were compared with the data from the research dedicated to the analysis of hypotactic structures of the adverbial type in the same manuscript.

KEY WORDS: Prološko žitije Svetog Maksima, Gavril Stefanović Venclović, Old Serbian language, historical syntax, clauses.

Мср Сања Петровић

Одсек за српски језик и лингвистику Филозофски факултет, Универзитет у Новом Саду Србија sanja.lj.petrovic@gmail.com 